\title{
Geoffrey of Monmouth in Portugal and Galicia
}

\author{
Santiago Gutiérrez García
}

The dissemination of the works of Geoffrey of Monmouth in medieval Portugal must be analyzed, aside from its peculiarities, within the broader context of the Hispanic kingdoms. Knowledge of Geoffrey's works in Portuguese lands accords with the dynamics of dissemination and circulation of texts in the central and western areas of the Iberian Peninsula, and shows strong connections to events happening in the neighboring kingdom of Castile-León. As in Castile-León, no copies of Geoffrey's work are documented in Portugal during the Middle Ages, while there are only a few allusions to his work that allow scholars to indirectly establish the presence of his work in West Iberia. This situation is somewhat paradoxical, since scholars have considered Portugal one of the main points of entry of the Matter of Britain into the Peninsula. There is no doubt, in fact, that the Atlantic coast of the Portuguese kingdom generated contact by sea with the peoples of northwestern Europe, especially those of Britain. ${ }^{1}$ Thus, for example, Portuguese ports were on several occasions layovers for Crusader expeditions on their way to the Mediterranean, or for Crusaders participating in the conquest of cities in central and south Portugal, such as Lisbon, which were taken with the help of the British in particular. And, in the same manner, the alliances that the kings of Portugal established with England - think, for example, of the wedding between João I and Philippa of Lancaster in 1387 - not only consolidated Portugal's recent independence from the kingdom of Castile-León, but also fostered Anglo-Portuguese commercial and cultural exchanges.

Nevertheless, despite the close contacts between northwest Europe and Portugal, the first evidence of Geoffrey's corpus in the kingdom is linked to the center of the Peninsula, as it derives from historiographical texts created in Castile, such as that of Alfonso x el Sabio ("the wise"). This monarch used the $D G B$ to write the General estoria (1270-84), which he referred to as the Estoria de las Bretannas. ${ }^{2}$ The title could be a reference to the $D G B$ directly or to some other history derived from Geoffrey's. Both options seem possible, because the

1 As a matter of fact, according to the Trojan origin story of the British people, the Portuguese coast was on the route that the Trojans would have taken on their way to Britain.

2 For additional discussion, see Paloma Gracia's contribution to this volume. 
General estoria makes note of a history of Britain written in Latin, from which Alfonso $\mathrm{x}$ took verbatim quotations. ${ }^{3}$ See, for example, the following passage, in which Brutus's visit to the temple of Diana is described: "and those words of Brutus's prayer are in that history of Britain in Latin, like all the other material from that book, and it reads as follows: Mighty goddess of the forest, terror of woodland boars ..." Galfridian accounts are scattered in succeeding passages throughout sections II to v of the General estoria, although, due to the unfinished nature of Alfonso's chronicle, they only go as far as the expedition of Julius Caesar.

Be that as it may, the General estoria did not take long to circulate throughout the westernmost of the Hispanic kingdoms, both in Spanish and in translations into Portuguese. Proof of the chronicle's dissemination is the several copies found in Portuguese libraries, such as the manuscript of the Public Library of Évora written in Castilian, or the manuscript of the Arquivo Distrital de Castelo Branco, and the five manuscripts of the Arquivo da Torre do Tombo de Lisbon - all written in Portuguese. ${ }^{5}$ Although the transmission of such an extensive text as the General estoria was carried out in a very fragmented way, and the extant copies found in Portugal do not contain the passages taken from the $D G B$, it is logical to suppose that the chronicle of Alfonso $\mathrm{x}$ spread the passages to the kingdom just as it served as a model for 14th-century Portuguese historiography.

One of the works that follows Alfonso's model is the Crónica Geral de Espanha de 1344 ("The 1344 General History of Spain"), composed $c .1344$ by Pedro Afonso (1287-1350), Count of Barcelos (henceforth referred to as D. Pedro) and son of King Dinis I. ${ }^{6}$ This chronicle has not survived in its original form, but in a redaction (c.1400) that has significant modifications. The redactor eliminated all

3 F. Gómez Redondo, "La materia de Bretaña y los modelos historiográficos: el caso de la General estoria”, e-Spania 16 (2013), <https://journals.openedition.org/e-spania/22707> (accessed zo May 2018), §14.

4 Alfonso x, General estoria, ed. P. Sánchez Prieto-Borja, A. Cabrejas, and M. Belén, General estoria. Segunda Parte, 2 vols., Madrid, 2009, vol. 2, p. 512. The manuscript states: "e aquellas palavras de la oración de Bruto son en aquella estoria de Bretaña en latín, como todas las otras razones d'ese libro, e dizen d'esta guisa: Diva potens nemorum, terror silvestribus apris ..." The italics in the body of the text and the translation are my own, signaling that the manuscript shifts languages from Spanish to Latin. The translation of the Latin is that of Neil Wright; see $D G B$, i.16.294.

5 Évora, Public Library, Cxxv 2/3; Castelo Branco, Arquivo Distrital, CNCVL/o1/Lvo14; Lisbon, Arquivo da Torre do Tombo, Fragmentos, cx. 13, mç. 10, n 30 , Fragmentos, cx. 21, no 29 , Fragmentos, cx. 21, $\mathrm{n}^{\mathrm{o}} 3 \mathrm{3}$, Fragmentos, cx. 21, $\mathrm{n}^{\mathrm{o}}$ 31, Fragmentos, cx. $21, \mathrm{n}^{\mathrm{o}} 32$.

6 Count Pedro of Barcelos, Crónica de 1344, ed. L.F. Lindley Cintra, Crónica geral de Espanha de 1344, Lisbon, 1952. 
the materials that were considered unrelated to the Hispanic kings. Those removed chapters would have included a brief summary of the history of Britain based on the $D G B$. The narration has been preserved in a Castilian translation of the original Crónica, available in Salamanca, University of Salamanca Library, 2656. In just one chapter, CCCXXI, the author outlines a tight summary of the last section of Geoffrey's $D G B$, from the death of Arthur and the succession to the throne of Lot de Leonís (Loth) and Constantín (Constantinus), until the lineage of the kings of Britain is extinguished after the death of Cavadres (Cadualadrus). The author ends the narration by recalling the ties between the monarchs of Britain and the kings of Troy, but not without cause, since his motive in including this summary is to relate the origins of the great European lineages and dynasties, and in this context he can insert the lineage of the kings of Spain.

A similar goal is found in the inclusion of another summary of the $D G B$, specifically in section II of the Livro de linhagens ("Book of Lineages") written by D. Pedro between 1340 and 1344. In this case, the account goes back to the reign of Dardanus of Troy, linking Priam, Aeneas, and Brutus with the lineage of the kings of Britain, and extends as far as the death of Cavadres (Cadualadrus) and the conquest of the island by the Saxons. It is, therefore, a summary of the whole of the $D G B$ except for the $P M$, which are not documented in Portugal. Its purpose would be the same as that of the Galfridian passages used in the Crónica Geral de Espanha de 1344, although this time with the intention of exalting noble Portuguese families.

In view of the details contained in these two excerpts, it can be concluded that D. Pedro did not use Geoffrey's $D G B$ directly, but some intermediate version, whose identification has caused some controversy among scholars. The successive contributions of Manuel Serrano y Sanz, Luís Filipe Lindley Cintra, and Diego Catalán have established that D. Pedro used a version of the Liber regum ("The Book of Kings"), a historiographical work written in Navarre between 1196 and $1209 .{ }^{7}$ Specifically, it is believed that he could have drawn on the Libro de las generaciones (c.1256-70), a composition derived from the

7 M. Serrano y Sanz, "Cronicón Villarense (Liber Regum). Primeros años del siglo XIII. La obra histórica más antigua en idioma español”, Boletín de la Real Academia Española, 6 (1919), 192-220 and 8 (1921), 367-82; L.F. Lindley Cintra, "O Liber Regum e outras fontes do Livro de Linhagens do Conde D. Pedro", Boletim de Filologia, 11 (1950), 224-51; id., "Uma tradução galego-portuguesa desconhecida do Liber Regum”, Bulletin Hispanique, $5^{2}$ (1950), 27-40; Count Pedro of Barcelos, Crónica de 1344, ed. Lindley Cintra; D. Catalán Menéndez-Pidal, De Alfonso X al Conde de Barcelos: cuatro estudios sobre el nacimiento de la historiografía romance en Castilla y Portugal, Madrid, 1962. 
oldest version of the Liber regum. ${ }^{8}$ Nevertheless, it cannot be ruled out that D. Pedro handled more than one version of the latter work or even a compilation based on another edited version of the Liber regum, the so-called Liber regum toletanus ("The Toledo Book of Kings", c.122o). Catalán himself proposed that this compilation could have been made in Mondoñedo, a city in northern Galicia with ecclesiastical links to the Portuguese town of Braga. ${ }^{9}$ Catalán did so by taking into account certain linguistic features and allusions from the texts, but above all he took into account the similarities that D. Pedro's narration of Galfridian episodes had with other works composed in the Iberian northwest - such as the Crónica de 1404 or the Galician version of the Crónica de Castilla. More recently, Bautista has reiterated the Galician origin of the supposed compilation, although proposing Santiago de Compostela as its place of origin. ${ }^{10}$

Another indirect reference reaffirms the difficulties of studying the dissemination of Geoffrey's corpus in Portugal because of its elusive nature and the scarcity of data on its circulation. Box and Deyermond, for example, call attention to a comment in chapter CXII of the Livro de Jose de Arimateia ("The Book of Joseph of Arimathea") made to a certain Mestre Baqua, "who translated the History of Britain into French from Latin". "1 The figure in question is Wace, who adapted the $D G B$ into French as the Roman de Brut. These two scholars mention the originality of the reference, since it is not found in other French or English versions of the work, and therefore cannot come from a foreign source. With some caution, they deduce that the mention of Wace does not imply a thorough knowledge of his work nor its direct handling. It would be enough for the Portuguese redactor to know of the importance of Wace in the dissemination of Arthuriana if he were searching for a prestigious reference with which to compare his own work. Be that as it may, the knowledge, even indirect, of Wace as the adapter of Geoffrey's $D G B$ into French demonstrates a certain familiarity with texts associated with Geoffrey's corpus on the part of authors in

8 Catalán Menéndez-Pidal, De Alfonso X, p. 365 .

9 D. Catalán Menéndez-Pidal, De la silva textual al taller historiográfico alfonsí. Códices, crónicas, versiones y cuadernos de trabajo, Madrid, 1997, p. 343.

10 F. Bautista, "Original, versiones e influencia del Liber regum: estudio textual y propuesta de stemma", e-Spania 9 (2010), <https://journals.openedition.org/e-spania/19884> (accessed 3 o May 2018), §36.

11 Estória do Santo Graal, ed. J.C. Ribeiro Miranda, Estória do Santo Graal. Livro Português de José de Arimateia. Manuscrito 643 do Arquivo Nacional da Torre do Tombo, Porto, 2016, p. 33o. The manuscript says "que traladou a Estoria de Brutos em framces de latim". See J.B.H. Box and A. Deyermond, "Mestre Baqua and the Grail Story", Revue de Littérature Comparée $5^{1}$ (1977), 366-70. 
the Iberian Peninsula, who might have also used the author of the Roman de Brut to enhance their own prestige.

In contrast, studies of the dissemination of Geoffrey of Monmouth's work in Portugal have privileged the search for texts written in Portuguese, paying less attention to medieval Latin texts. Nevertheless, an analysis of the works in Latin found in Portuguese libraries that would have circulated during the Middle Ages can shed additional light to the data exposed so far. To give just one example, the Speculum historiale by Vincent de Beauvais (1240-60) used the $D G B$ as one of its sources. Several copies of the work of this French Dominican are kept in Portuguese libraries, both as manuscripts (Lisbon, National Library of Lisbon, Il.135, Il.126-128, and Il.130-131), as well as incunables in the Public Library of Évora, the National Library of Lisbon, the University Library of Coimbra, and the Arquivo Municipal de Castelo Branco. There are also incunable copies of the Chronicon by Antoninus of Florence (1477) in the National Library of Lisbon and the Public Library of Évora. Antoninus took as his main source the Speculum historiale and, through it, repeated many passages from Geoffrey, thus contributing, albeit indirectly, to the dissemination of his work.

The above information allows us to conclude that in Portugal, Geoffrey was known in an indirect and partial way, which demonstrates, paradoxically, how the immense popularity of his $D G B$ achieved great geographical reach, disseminated in a wide variety of ways.

Translated from Spanish by Nahir I. Otaño Gracia 